\title{
IMPROVEMENT OF THE METHOD OF CONCRETE PHYSICAL AND MECHANICAL PROPERTIES DETERMINATION BY NON-DESTRUCTIVE METHODS
}

\author{
Kolokhov V.V., Ph.D., Associate Professor, \\ kolokhov.viktor@pgasa.dp.ua, ORCID: 000-0001-8223-1483 \\ Prydniprovska State Academy of Civil Engineering and Architecture \\ Chernyshevskoho, 24-a, Dnipro, 49600, Ukraine
}

\begin{abstract}
To ensure the reliability of existing buildings, facilities and building structures, objective information is required, the receipt of which is mainly associated with the use of nondestructive methods of control. Current normative documents regulate the strength and deformability characteristics of the material, which are used mainly in the design of structures. The normalized value is obtained on the basis of probabilistic and statistical processing and is characterized by some conditional value. Improvement of methods of calculation of constructions connected with the account of elastic-plastic properties of concrete is based on application of the standardized diagrams of work of concrete received on the basis of laboratory experiments. In the real structure due to differences in the composition of laboratory and real concrete, technologies of its manufacture and laying, there may be significant differences from the acquired value "Concrete strength" and "Modulus of elasticity", which was taken to calculate the structure.

The above-mentioned influence of the stress level on the readings of the device in determining the strength of concrete by non-destructive testing methods was investigated on concrete samples of six different compositions. Concrete cubes measuring $150 \times 150 \times 150 \mathrm{~mm}$ were used to study the stated assumptions.

The determination of the strength of concrete samples by the non-destructive method was performed. A sclerometer (Schmidt's Hammer MSH-225) was used to determine, which implements the method of elastic rebound. The determination was performed at different load levels, which was added to the test sample, followed by determination of the strength of concrete on a hydraulic press with a load up to $1250 \mathrm{kN}$.

The analysis of the obtained results shows that the attempt to obtain a generalized calibration curve, which would take into account the change in the stress level in the structure, leads to a decrease in the accuracy of determining the physical and mechanical characteristics of concrete. The presented dependences demonstrate the significance of the influence of the stress level in the structural element on the results of determining the physical and mechanical characteristics of concrete by non-destructive methods. The analysis of these dependences shows the need to modernize non-destructive methods for determining the physical and mechanical characteristics of concrete.
\end{abstract}

Keywords: concrete, physical and mechanical characteristics, non-destructive testing.

Introduction. Non-destructive testing (NC) methods, which are most common in the production of concrete and reinforced concrete structures, are showing of the deformable properties $\left(\mathrm{E}_{\mathrm{k}}\right)$ of their material. The results of $E_{k}$ measurements depend on the structure of the concrete $\left(S_{b}\right)$ and the magnitude and nature of the effects on the structure (I). The structure of concrete is usually determined by the composition of the concrete mixture $\left(\mathrm{C}_{\mathrm{bm}}\right)$, the technology of its laying $\left(\mathrm{T}_{\mathrm{lcm}}\right)$ and the conditions of hardening of concrete $\left(\mathrm{C}_{\mathrm{hc}}\right)$. Influences on the structure are usually divided into force loads $\left(\mathrm{I}_{\mathrm{p}}\right)$ and non-force actions $\left(\mathrm{I}_{\mathrm{np}}\right)$. Given the ambiguity and nonlinearity of the influence of various factors, the generalized deformative properties of the structural material can be represented as a functional $\mathrm{E}_{\mathrm{k}}=\mathrm{F}$ $\left(S_{b}, I\right)$, where $S_{b}$ and $I$ are functional. Accordingly, $S_{b}=F\left(C_{b m}, T_{l c m}, C_{h c}\right)$, and $I=F\left(I_{p}, I_{n p}\right)$. In this case, the scope of these functionalities is given by the limiting parameters of the existence of the structure. If we consider such a normalized characteristic of concrete as the compressive strength $\mathrm{f}_{\mathrm{ck}}$ as the limit value of the functional $\mathrm{E}_{\mathrm{k}}$, then determining the modulus of elasticity of concrete (based on the results of $\mathrm{NC}$, which is now standardized to determine its compressive strength) - is the solution of

Bulletin of Odessa State Academy of Civil Engineering and Architecture, 2021, no. 82, page 82-89 
the inverse problem. With significant nonlinearity and multifactorial dependences linking these values, the transition to the solution of the direct problem will significantly increase the accuracy of determining the physical and mechanical characteristics (FMC) of the structural material and, consequently, the accuracy and reliability of test calculations.

Analysis of recent research and publications. Modern studies of the application of nondestructive methods for determining the physical and mechanical characteristics of concrete are devoted to the detection of defects in the structure of concrete [1-3]. These works, and many others, are based on the relationship between $\mathrm{f}_{\mathrm{ck}}$ and $\mathrm{E}_{\mathrm{b}}$ (modulus of elasticity), which, for example, are provided in the normative document in tabular form [4-6]. For these standards are given almost identical values of strength and modulus of elasticity (Fig. 1).

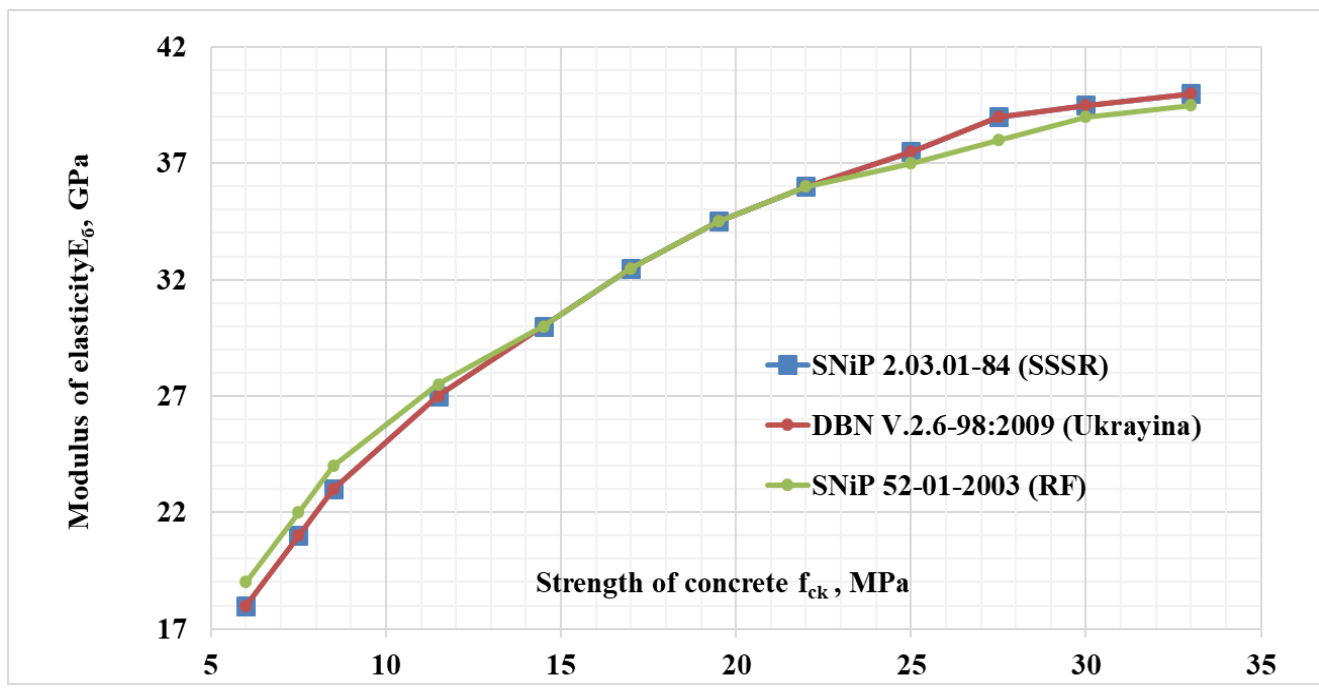

Fig. 1. Dependencies strength - modulus of elasticity

For the given dependence of the elasticity modulus value is characterized by a gradual decrease in the growth of concrete elasticity modulus with increasing strength. For low-strength concretes, the difference between the values of concretes elasticity modulus of close classes is $36.8 \ldots 16.7 \%$, for medium-strength concretes $-17.4 \ldots 8.3 \%$, and for high-strength concretes $6.2 \ldots 4.0 \%$.

In Fig. 2 shows a graphical interpretation of the influence of the rheological properties of the concrete mixture on the value of concrete elasticity modulus according to the norms of the Republic of Belarus [7] in comparison with the similar relationship between fck and $\mathrm{E}_{\mathrm{b}}$ according to [5].

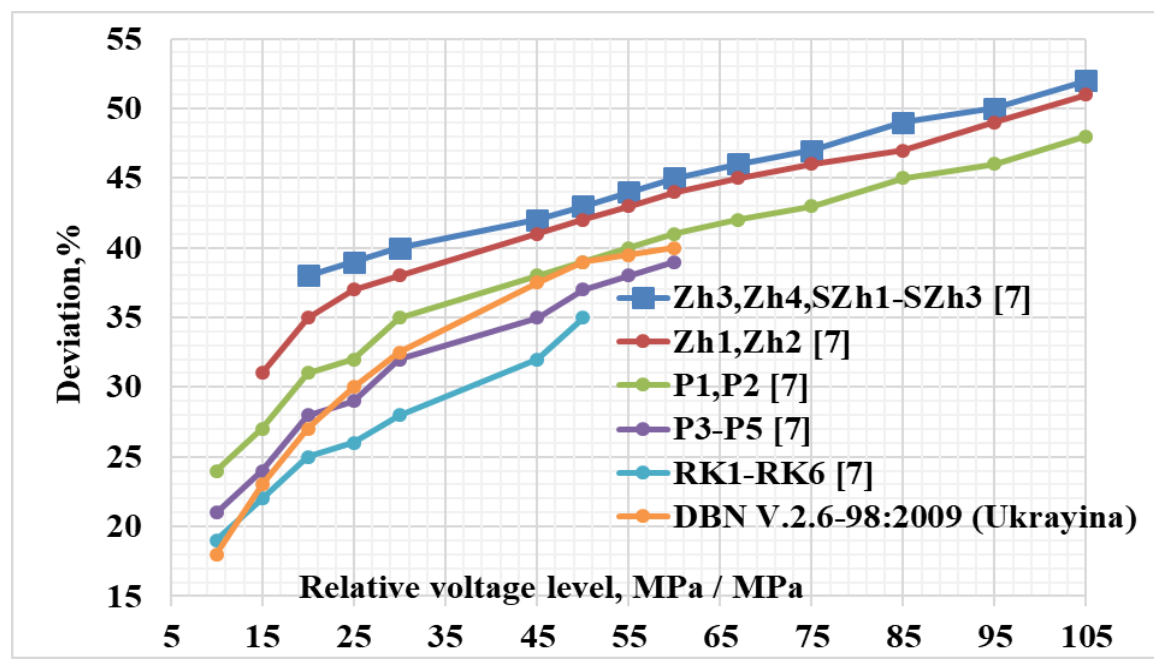

Fig. 2. Graphical interpretation of the relationships between concrete strength, rheological properties of concrete mix and modulus of elasticity of concrete 
Thus, the transition from $f_{c k i}$ to $E_{b i}$, using the provisions of regulations, leads to significant uncertainty and, consequently, to further reduce the accuracy of the RDP design results. That is, with this approach, we can talk about reducing the accuracy of determining the FMC of the structural material on $\Delta \mathrm{f}_{\mathrm{ck}} / \mathrm{f}_{\mathrm{cki}}$, which is already established during the normalization of FMC. Technological personalities of concrete production of reinforced concrete structures only increase the uncertainty of the results of NC methods application.

Existing normative documents [8-12] regulate the strength and deformability characteristics of the material, which are used mainly in the design of structures. The normalized value is obtained on the basis of probabilistic and statistical processing and is characterized by some conditional value. Improvement of designs calculation methods is connected with the account of elastic-plastic properties of concrete are based on application of the standardized diagrams of work of concrete received on the basis of laboratory experiments. In the real structure due to differences in the composition of laboratory and real concrete, technologies of its manufacture and laying, there may be significant differences from the acquired value "Concrete strength" and "Modulus of elasticity", which was taken to calculate the structure.

Experiments [13] conducted with samples of heavy and expanded clay concrete and heavy concrete, which were taken during the reconstruction of the wall expanded clay concrete panels of a multi-storey panel house showed a significant effect of stress level in the structure and composition of concrete on the measurement results.

Existing methods for determining the strength do not allow to implement in practice the obtained in the laboratory calibration dependences adequately. The inadequacy of interpretation is explained by the fact that:

- the dependences used by the devices are functionals of the type "indirect value measured by the device under local action - the value of the destructive load on the standard sample";

- the dependences used are obtained by interpolating the results of measurements in the laboratory and, as a rule, do not take into account the peculiarities of the formation of the structure of the structural material and take into account changes in the properties of the structural material over time;

- the accuracy of measurements is influenced by the physical and mechanical characteristics of the contact zone in the interaction "device - concrete", the formalization of the parameters of such a zone by current regulations is not clear enough.

The purpose of the work. Determining the possibility of obtaining a generalized calibration dependence for determining the physical and mechanical characteristics of concrete structure by the method of elastic rebound.

Materials and research methods. The above-mentioned influence of the stress level on the instrument readings when determining the strength of concrete by non-destructive methods of control was investigated on concrete samples of different compositions (C12/15, C16/20 and C20/25). The working warehouses of concrete of one of the producers of ready-mixed concrete in Dnipro were chosen as a basis. According to the agreements with the manufacturer, the composition of concrete and its physical and mechanical characteristics are not disclosed, so the research results are given in relative parameters. Each of the concrete compositions was modified to provide different mobility of the mixture. Six compositions for each class of concrete were obtained. Concrete cubes measuring $150 \times 150 \times 150 \mathrm{~mm}$ were used. The design of concrete mix compositions was carried out to ensure equal compressive strength of concrete samples, which was obtained.

The determination of the strength of concrete samples by the non-destructive method was performed. A sclerometer (Schmidt's Hammer MSH-225) was used to determine, which implements the method of elastic bounce [9]. The determination was performed at different load levels, which was added to the test sample, followed by determination of the strength of concrete on a hydraulic press with a load up to $1250 \mathrm{kN}$.

Research results. For each series of three samples, the strength was determined by the elastic rebound method. The samples were loaded with steps during their fixation in the press. Determination of strength was performed using the calibration dependence. The results of statistical processing to determine the physical and mechanical characteristics of concrete at different stress levels in concrete samples of class C16/20 are presented in Fig. 3. The available deviations of the

Bulletin of Odessa State Academy of Civil Engineering and Architecture, 2021, no. 82, page 82-89 
strength dependence of concrete calculated by means of calibration dependence on value of durability which was received by press measurement are resulted.

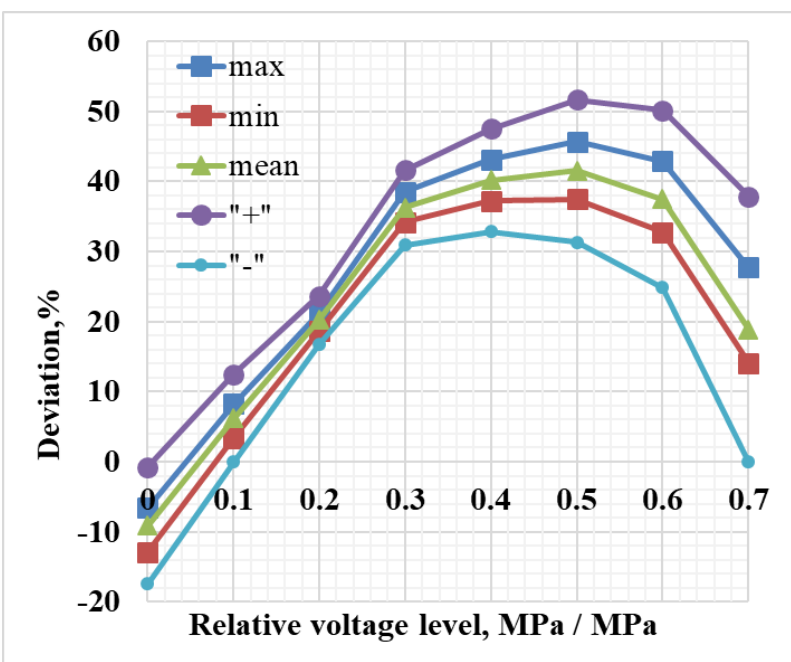

a)

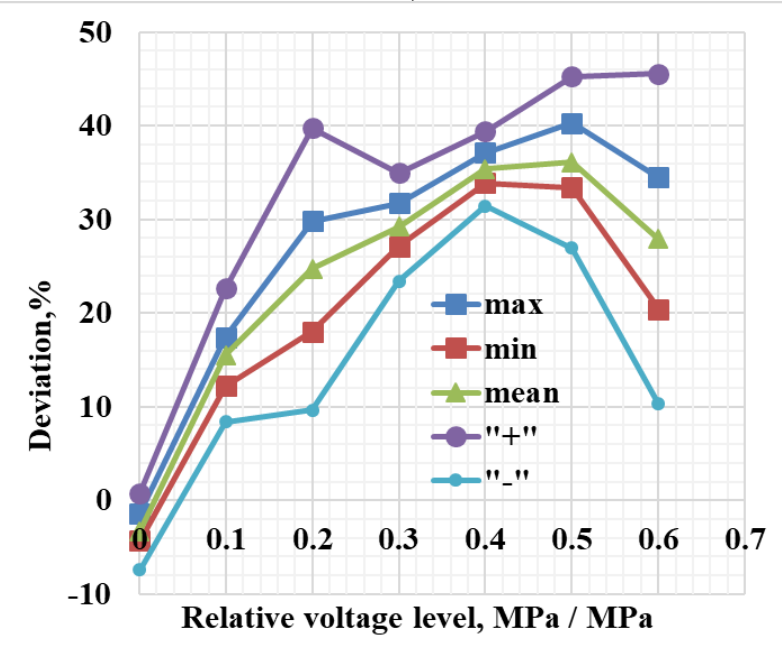

c)

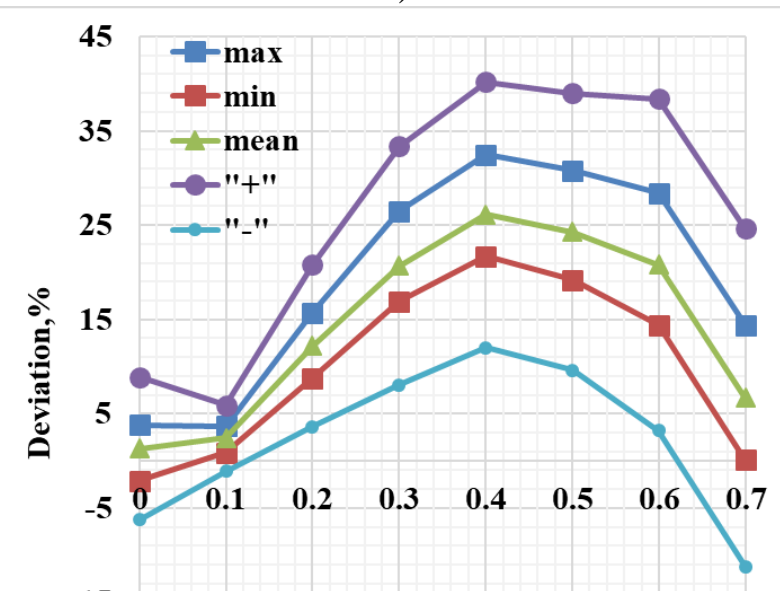

Relative voltage level, MPa / MPa

e)

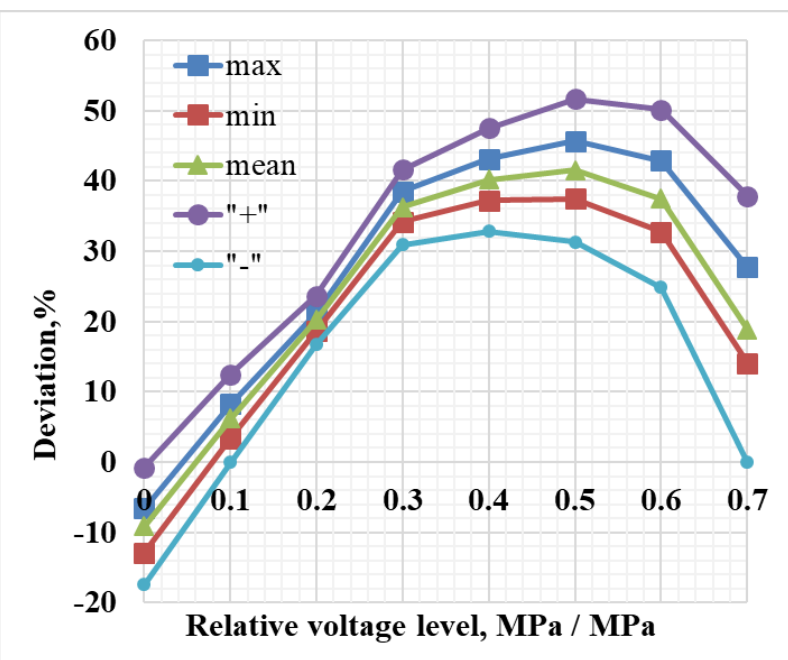

b)

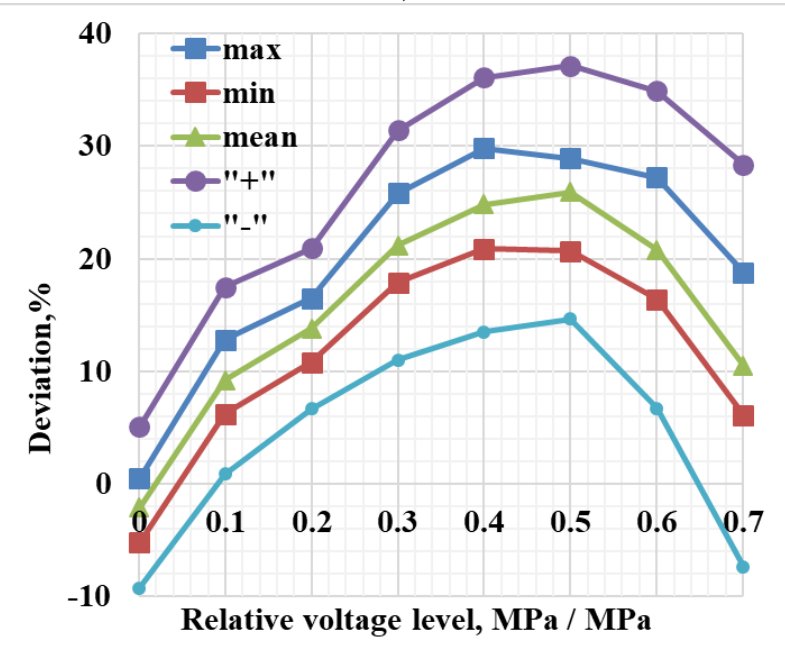

d)

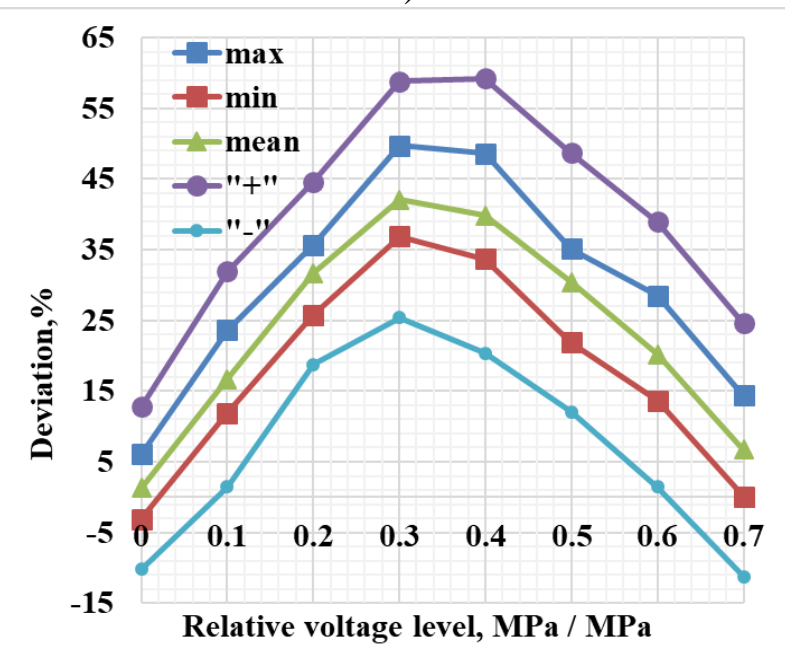

f)

Fig. 3. The results of statistical processing to determine the physical and mechanical characteristics of concrete at different stress levels in concrete samples of class C16/20: $\mathrm{a}$ - for composition 1 ; $\mathrm{b}$ - for composition 2 ; $\mathrm{c}$ - for composition 3 ; $\mathrm{d}$ - for composition 4 ; $\mathrm{e}-$ for composition $5 ; \mathrm{f}$ - for composition 6 
According to the test results, the dependences of the influence of the measurement results on the stress level in the concrete are obtained, which are quite adequate.

The combination of the obtained results in one coordinate system for concrete of one class is given in Fig. 4.

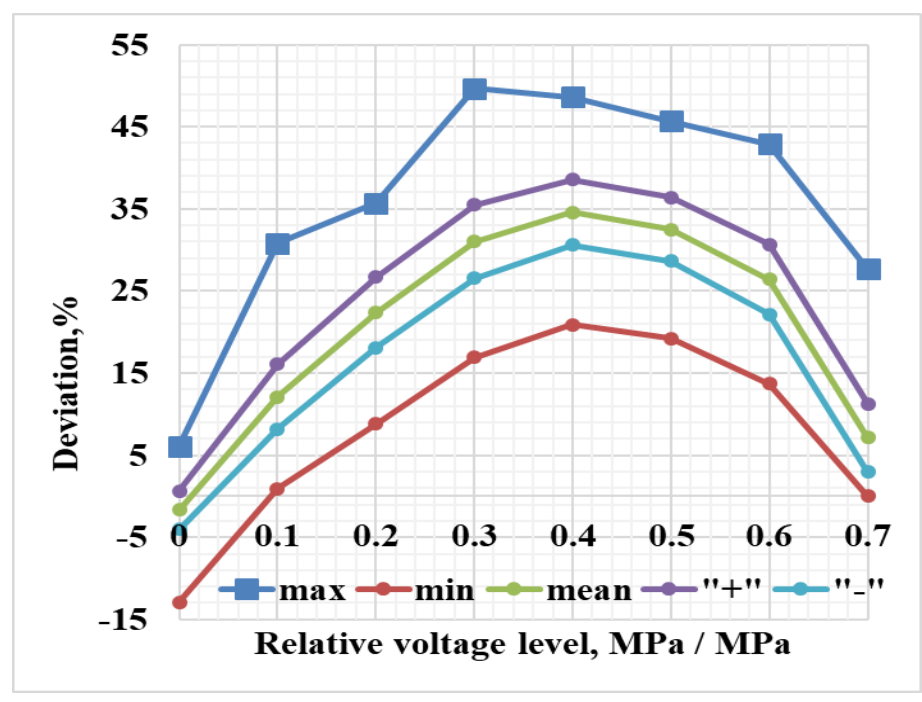

Fig. 4. The results of statistical processing to determine the physical and mechanical characteristics of concrete at different stress levels in samples of concrete class C16/20 with different rheological properties of concrete mixtures

A certain number of results lies outside the confidence interval. The analysis of the obtained results shows that the attempt to obtain a generalized calibration curve, which would take into account the change in the stress level in the structure, leads to a decrease in the accuracy of determining the physical and mechanical characteristics of concrete.

The analysis of the presented dependences shows the significance of the influence of the stress level in the structural element in determining the physical and mechanical characteristics of concrete. That is, it is necessary to take into account the stress level in the structural element when determining the physical and mechanical characteristics of concrete and to modernize the scheme of verification, which is given in [14]. This scheme should be presented in the form shown in Fig. 5.

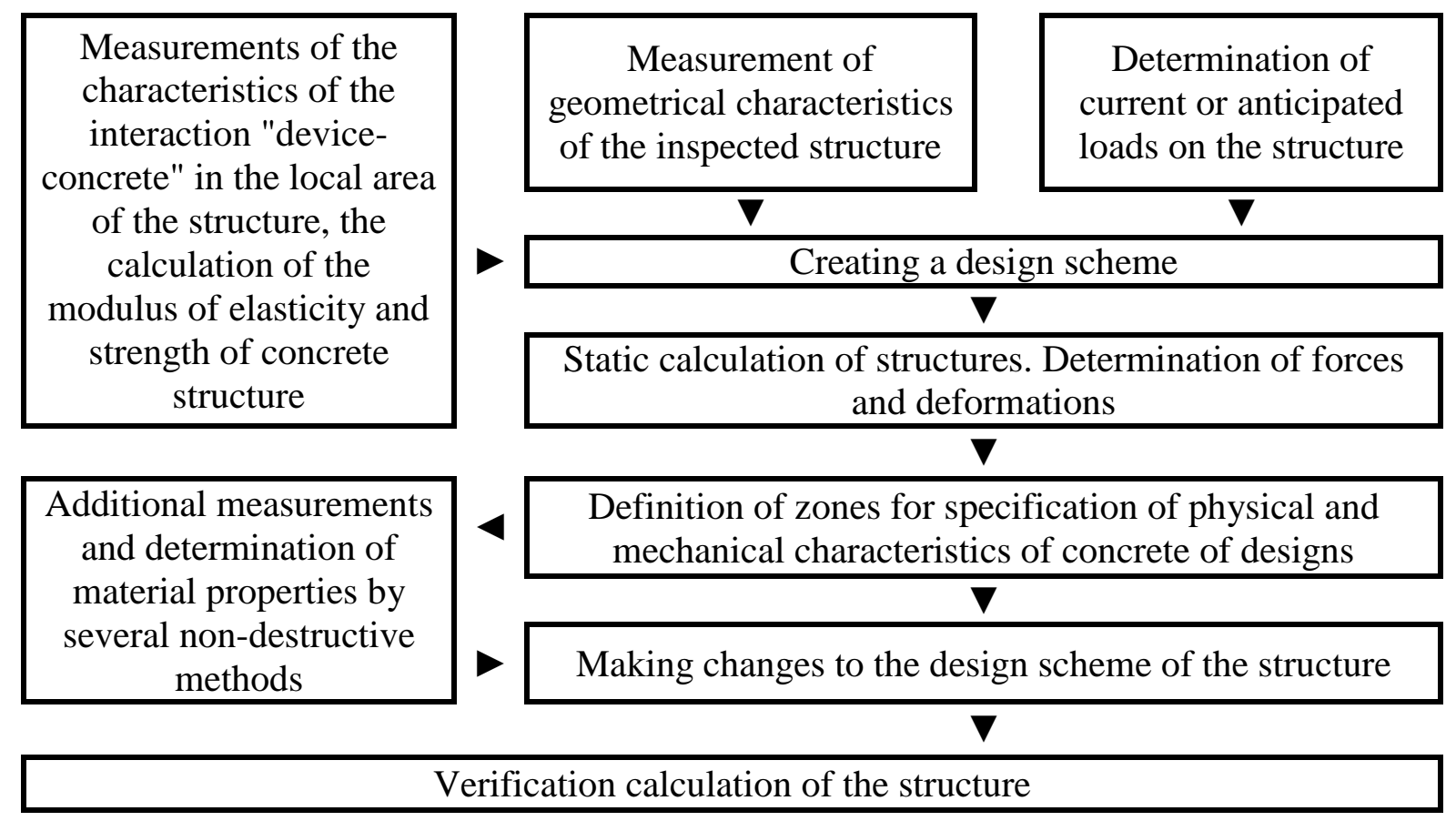

Fig. 5. Scheme of operations for verificationusing the results of determining the strength of concrete by non-destructive testing 
Conclusions and prospects for further research. Based on the above, you can conclude the following:

- The methods used in construction to determine the mechanical properties of concrete in structures require improvement, both methodologically and in terms of equipment.

- The proposed circuit solutions will increase the accuracy of determining the physical and mechanical characteristics of concrete in the structure and, consequently, the adequacy of the assessment of the technical condition of building structures.

- Further increase in accuracy can be achieved through the development of direct methods for determining the modulus of elasticity of concrete structures in operation.

\section{References}

[1] K. Mori Spagnoli, Y. Murakami, G. Kondo, I. Torigoe, "A new non-contacting nondestructive testing method for defect detection in concrete", NDT and E International, vol. 35, iss. 6, pp. 399-406, 2002.

[2] K. Schabowicz, "Ultrasonic tomography - The latest nondestructive technique for testing concrete members - Description, test methodology, application example", Archives of Civil and Mechanical Engineering, vol. 14, iss. 2, pp. 295-303, 2014.

[3] Jun Chen, Zheng Xu, Yue Yu, Yangping Yao, "Experimental characterization of granite damage using nonlinear ultrasonic techniques", NTD and E International. Editor-in-chief D.E. Chimenti, vol. 67, pp. 10-16, 2014.

[4] СНиП 2.03.01-84. Бетонные и железобетонные конструкции / Госстрой СССР. Введ. 1986-01-01. - Москва : ЦИТП Госстроя СССР. 1985. - 79 с

[5] DBN V. 2.6-98:2009. Konstrukciyi budinkiv i sporud. Betonni ta zalizobetonni konstrukciyi. Osnovni polozhennya. [Na zaminu SNiP 2.03.01-84*]; chinni vid 2011.06.01. Kiyiv: Minregionbud Ukrayini, 2009.

[6] Cvod pravil SP 63.13330.2018. Betonnye i zhelezobetonnye konstrukcii. Osnovnye polozhennya. SNiP 52-01-2003. (SP 63.13330.2018. Betonnye i zhelezobetonnye konstrukcii. Aktualizirovannaya redakciya SNiP 52-01-2003. M., 2018. [Online]. Available: https://www.srosp.ru/upload/files/doc/SP-63_.pdf;)

[7] SNB 5.03.01-02. Betonnye i zhelezobetonnye konstrukcii. Ministerstvo arhitektury i stroitelstva Respubliki Belarus. Minsk.: Strojtehnorm, 2003.

[8] DSTU B V. 2.7-217:2009. Budivelni materiali. Betoni. Metodi viznachennya prizmovoyi micnosti, modulya pruzhnosti i koeficiyenta Puassona. Kiyiv: Minregionbud Ukrayini, 2010.

[9] DSTU B V. 2.7-220:2009. Budivelni materiali. Betoni. Viznachennya micnosti mehanichnimi metodami nerujnivnogo kontrolyu. Kiyiv: Minregionbud Ukrayini, 2010.

[10] DSTU B V. 2.7-223:2009. Budivelni materiali. Betoni metodi viznachennya micnosti za zrazkami, vidibranimi z konstrukcij: Kiyiv: Minregionbud Ukrayini, 2010.

[11] DSTU B V. 2.7-224:2009. Budivelni materiali. Betoni pravila kontrolyu micnosti. Kiyiv: Minregionbud Ukrayini, 2010.

[12] DSTU B V. 2.7-226:2009. Budivelni materiali. Betoni. Ultrazvukovij metod viznachennya micnosti. Kiyiv: Minregionbud Ukrayini, 2010.

[13] V.V. Kolohov, Yu.O. Kozhanov, D.M. Zezyukov, "Vpliv rivnya naprugi u betoni konstrukcij na shvidkist ultrazvuku", Visnik Pridniprovskoyi derzhavnoyi akademiyi budivnictva ta arhitekturi, no. 1, pp. 49-57, 2019.

[14] V.V. Kolokhov, "Nekotorye aspekty primeneniya metodov nerazrushayuschego kontrolya svojstv betona", Theoretical Foundations of Civil Engineering. Warsaw, vol. 20, pp. 443-448, 2012. 


\title{
ВДОСКОНАЛЕННЯ МЕТОДИКИ ВИЗНАЧЕННЯ ФІЗИКО-МЕХАНІЧНИХ ВЛАСТИВОСТЕЙ БЕТОНУ НЕРУЙНІВНИМИ МЕТОДАМИ
}

\author{
Колохов В.В., к.т.н., доцент, \\ kolokhov.viktor@pgasa.dp.ua, ORCID: 000-0001-8223-1483 \\ Придніпровська державна академія будівництва та архітектури \\ Чернишевського, 24-а, м. Дніпро, 49600, Україна
}

\begin{abstract}
Аннотация. Для забезпечення надійності експлуатованих будівель, споруд i будівельних конструкцій потрібна об'єктивна інформація, отримання якої здебільшого пов'язано із застосуванням неруйнівних методів контролю. Діючі нормативними документи регламентують міцністні та деформативні характеристики матеріалу, які використовуються в основному при проектуванні конструкцій. При цьому нормована величина отримана на підставі ймовірносно-статистичної обробки і характеризується деякою умовною величиною. Вдосконалення методів розрахунку конструкцій пов'язане з урахуванням пружно-пластичних властивостей бетону грунтується на застосуванні стандартизованих діаграм роботи бетону, отриманих на підставі лабораторних експериментів. У реальній конструкції у зв'язку 3 відмінностями в складах лабораторного і реального бетону, технологіях його виготовлення і укладання можуть спостерігатися значні відмінності від набутого значення «Міцність бетону» $\mathrm{i}$ «Модуль пружності», яку прийняли для розрахунку конструкції.

Відмічений вище вплив рівня напруги на показання приладу при визначенні міцності бетону неруйнівними методами контролю було досліджено на зразках бетону шести різних складів. Для вивчення висловлених припущень проведенні вимірів були використані бетонні куби розміром $150 \times 150 \times 150$ мм.

Виконано визначення міцності бетонних зразків неруйнівним методом. Для визначення використовувався склерометр (Молоток Шмідта МШ-225), що реалізує метод пружного відскоку. Визначення проводилося при різному рівні навантаження, що додавалося до випробовуваного зразка, з подальшим визначенням міцності бетону на гідравлічному пресі 3 навантаженням до 1250 кН.
\end{abstract}

Аналіз отриманих результатів показує, що спроба отримати узагальнену тарувальну криву, яка враховувала б зміну рівня напруги в конструкції, призводить до зниження точності визначення фізико-механічних характеристик бетону. Представлені залежності демонструють істотність впливу рівня напруги в елементі конструкції на результати визначення фізико-механічних характеристик бетону неруйнівними методами. Аналіз цих залежностей показує потребу модернізації неруйнівних методів визначення фізикомеханічних характеристик бетону.

Ключевые слова: бетон, физико-механические характеристики, неразрушающий контроль. 


\title{
СОВЕРШЕНСТВОВАНИЕ МЕТОДИКИ ОПРЕДЕЛЕНИЕ ФИЗИКО- МЕХАНИЧЕСКИХ СВОЙСТВ БЕТОНА НЕРАЗРУШАЮЩИМИ МЕТОДАМИ
}

\author{
Колохов В.В., к.т.н., доцент, \\ kolokhov.viktor@pgasa.dp.ua, ORCID: 000-0001-8223-1483 \\ Приднепровская государственная академия строительства и архитектурь \\ Чернышевского, 24-а, Днепр, 49600, Украина
}

\begin{abstract}
Аннотация. Для обеспечения надежности эксплуатируемых зданий, сооружений, строительных конструкций нужна объективная информация, получение которой в основном связано с применением неразрушающих методов контроля. Действующие нормативные документы регламентируют прочностные и деформативные характеристики материалов, используемые в основном при проектировании конструкций. При этом нормированная величина получена на основании вероятностно-статистической обработки и характеризуется некоторой условной величиной. Совершенствование методов расчета конструкций связано с учетом упруго-пластических свойств бетона основывается на применении стандартизированных диаграмм работы бетона, полученных на основании лабораторных экспериментов. В реальной конструкции в связи с различиями в составах лабораторного и реального бетона, технологиях его изготовления и укладки могут наблюдаться значительные отличия от полученного значения «Прочность бетона» и «Модуль упругости», которую приняли для расчета конструкции.
\end{abstract}

Отмечено выше влияние уровня напряжения на показания прибора при определении прочности бетона неразрушающими методами контроля были исследованы на образцах бетона шести различных составов. Для изучения высказанных предположений проведения измерений были использованы бетонные кубы размером 150×150×150 мм.

Выполнено определение прочности бетонных образцов неразрушающим методом. Для определения использовался склерометр (Молоток Шмидта МШ-225), реализующей метод упругого отскока. Определение проводилось при различном уровне нагрузки, добавлялось к испытываемому образцу, с последующим определением прочности бетона на гидравлическом прессе з нагрузкой до 1250 кН.

Анализ полученных результатов показывает, что попытка получить обобщенную тарировочную кривую, которая учитывала бы изменение уровня напряжения в конструкции, приводит к снижению точности определения физико-механических характеристик бетона. Представленные зависимостей показывают существенность влияния уровня напряжения в элементе конструкции при определении физико-механических характеристик бетона. Анализ этих зависимостей показывает необходимость модернизации неразрушающих методов определения физико-механических характеристик бетона.

Ключевые слова: бетон, физико-механические характеристики, неразрушающий контроль.

Стаття надійшла до редакції 8.02.2021

Bulletin of Odessa State Academy of Civil Engineering and Architecture, 2021, no. 82, page 82-89 